\title{
Cell-Mediated Immunity
}

National Cancer Institute

\section{Source}

National Cancer Institute. Cell-Mediated Immunity. NCI Thesaurus. Code C16711.

Those manifestations of the immune response which are mediated by antigen-sensitized

T-lymphocytes via lymphokines or direct cytotoxicity. This takes place in the absence of circulating antibody or where antibody plays a subordinate role. 